\title{
Mozaika ideowa, czyli o doktrynie politycznej społeczeństwa polskiego. Recenzja
}

\section{Autorzy: Zbigniew Rau, Katarzyna M. Staszyńska, Maciej Chmieliński, Krzysztof Zagórski}

Wydawnictwo: Wydawnictwo Naukowe Scholar

Miejsce wydania: Warszawa

Rok wydania: 2018

Liczba stron: 416

„Jaki to dziwny naród, ci Polacy!"2. Te słowa Kornela Makuszyńskiego, pomimo upływu lat, zdają się nadal trafnie oddawać naturę Polaków. Potwierdza to także nowa, napisana przez: Zbigniewa Rau, Katarzynę M. Staszyńską, Macieja Chmielińskiego i Krzysztofa Zagórskiego książka, ukazująca przekonania i poglądy Polaków na tle wybranych koncepcji klasycznej filozofii politycznej33.

Publikacja stanowi efekt wspólnej pracy nauk filozofów prawa, filozofów polityki i mających wieloletnie doświadczenie w prowadzeniu badań empirycznych socjologów.

Autorzy we wprowadzeniu jasno określili cel i ideę, które im przyświecały podczas opracowywania założeń i realizacji całego przedsięwzięcia. Zauważyli,

1 Karolina Sterna-Zielińska - karolina_sterna@o2.pl; ORCID: 0000-0002-0359-1833.

2 K. Makuszyński, Ponure igraszki, Warszawa-Kraków-Lublin-Łódź-Paryż-Poznań-Wilno-Zakopane 1927, s. 4.

3 Prof. Zbigniew Rau jest profesorem nauk prawnych, kierownikiem Katedry Doktryn Polityczno-Prawnych oraz Centrum Myśli Polityczno-Prawnej im. Alexisa de Tocqueville'a Uniwersytetu Łódzkiego. Prof. Krzysztof Zagórski jest profesorem socjologii, kierownikiem Centrum Socjologii Empirycznej w Akademii Leona Koźmińskiego. Obaj profesorowie byli wykładowcami wielu zagranicznych uczelni i są autorami szeregu publikacji naukowych. Dr Katarzyna Staszyńska jest doktorem socjologii, specjalistą z zakresu metodologii i etyki badań społecznych i marketingowych. Natomiast dr Maciej Chmieliński jest doktorem habilitowanym nauk prawnych, profesorem Uniwersytetu Łódzkiego, pracownikiem Katedry Doktryn Polityczno-Prawnych oraz członkiem Centrum Myśli Polityczno-Prawnej im. Alexisa de Tocqueville’a Uniwersytetu Łódzkiego. 
że „aby przetrwać, rozwijać się i spełniać pokładane w niej nadzieje, demokracja powinna (...) zostać wzbogacona, zarówno teoretycznie, jak i praktycznie, przez ustalenie podstaw woli społeczeństwa, czyli obywateli"'.

Publikacja rozpoczyna się szczegółowym przedstawieniem założeń metodologicznych. Na początku ustalono kategorie właściwe dla filozofii politycznej i określono znaczenia, jakie przypisywali im poszczególni klasycy. Następnie w starannie i rzetelnie przeprowadzonych badaniach jakościowych i ankietowych w Polsce ustalono, jakie znaczenie tym kategorią przypisują „zwykli ludzie w dyskursie potocznym", by w konsekwencji na ich podstawie skonstruować doktrynę polityczną "zbiorowego, pluralistycznego podmiotu, jakim jest społeczeństwo polskie" ${ }^{\prime \prime}$.

Autorzy w kolejnych rozdziałach koncentrują się już szczegółowo na opisie pięciu klasycznych kategorii, którymi są: człowiek, społeczeństwo, własność, władza oraz państwo.

Badania dotyczące rodziny nie zaskakują i ukazują, że niezmiennie od wielu lat dla Polaków najbardziej wartościową, najważniejszą w życiu wartością, która „nie powinna zostać poświęcona dla żadnego innego dobra” jest rodzina ${ }^{6}$. Rodzina jest tak istotna, bo zaspokaja „wielorakie, choć trudne do jednoznacznego i konkluzywnego uchwycenia, najbardziej naturalne potrzeby"7.

Pozytywnie zaskakują jednak dane przywoływane przy analizie kolejnej kategorii, z których wynika, że wspólnota lokalna, którą mogą stanowić zarówno sąsiedzi, przyjaciele, jak i współmieszkańcy wsi czy miasta jest również traktowana przez Polaków w sposób afirmatywny.

Wspólnota narodowa to dla większości Polaków powód do dumy. Z przeprowadzonych badań wynika bowiem, że Polacy są dumni zarówno ze swojej ojczyzny, jej historii, jak i sławnych rodaków. Ponadto, co również napawa optymizmem, większość z badanych uważa, że „bycie Polakiem skłania do tego, żeby dbać o dobro wszystkich Polaków, żeby być lepszym, bardziej się starać we wszystkim,

$4 \quad$ Z. Rau, K. M. Staszyńska, M. Chmieliński, K. Zagórski, Doktryna Polaków..., s. 7.

5 Ibidem, s. 14. Badanie jakościowe obejmowało zogniskowane wywiady grupowe, które zostały przeprowadzone w czterech regionach Polski. Badanie ankietowe przeprowadzono zaś w czerwcu 2014 r. na losowo dobranej próbie 934 dorosłych Polaków.

6 Ibidem, s. 54. Potwierdza to również raport CBOS, w którym rodzinę jako najważniejszą wartość wskazało $80 \%$ proc. ankietowanych. „Rodzina niezmiennie pozostaje podstawową komórką życia społecznego, a szczęście rodzinne uważane jest za jedną z podstawowych wartości i cel życiowy wielu Polaków", Raport CBOS, Rodzina - jej znaczenie i rozumienie, nr 22/2019.

7 Z. Rau, K. M. Staszyńska, M. Chmieliński, K. Zagórski, Doktryna Polaków..., s. 56. 
co się robi, a gdyby Polska była w niebezpieczeństwie ludzie gotowi by byli poświęcić się dla ojczyzny"8.

Ten niemal idylliczny, bardzo zbliżony do arystotelesowskiej wizji społeczeństwa obraz Polaków zmienia się diametralnie wraz z kolejnym obszarem badań, opiniami Polaków na temat stosunków społecznych. Z odpowiedzi respondentów wyłania się bowiem aspołeczna, egoistyczna, nieskora do poświęceń natura Polaków. Zapytani o wzajemne stosunki między ludźmi, ankietowani w większości zgodzili się ze stwierdzeniami, że: „w naszym społeczeństwie wszyscy wszystkim wszystkiego zazdroszczą", „ludziom zależy na tym, żeby mieć więcej niż inni”, i dodatkowo "ludzie nie troszczą się o siebie nawzajem" ${ }^{\prime 9}$. Znakomicie zbiegające się z wizją T. Hobbesa przekonanie o egoizmie i aspołeczności człowieka w przypadku Polaków na szczęście łagodzone jest jednak wiarą we współpracę i przekonaniem, że „ludzie powinni mieć do siebie więcej zaufania”10. Jak zaznaczyli autorzy, przeprowadzenie tego rodzaju badań wynikało z potrzeby uzupełnienia analiz dotyczących wspólnot, o obraz „relacji w stosunkach społecznych niezależnie od tych wspólnot, czy wręcz poza nimi"11. Gdyby zatem pokusić się na ich podstawie o receptę szczęśliwego życia dla narodu, jakim są Polacy, należało by jednoznacznie napisać na niej: „zalecane trwanie we wspólnocie”. Jak wynika bowiem z analiz zaprezentowanych w publikacji, bycie we wspólnocie daje Polakom sens życia, poczucie bezpieczeństwa, szacunku i motywuje do tego, aby być lepszymi ludźmi. Potwierdzałoby to zresztą tezę, że człowiek, którego natura od urodzenia skażona jest egoizmem, potrafi ją przezwyciężyć tylko ze względu na wartości, które są dla niego ważne, a w przypadku Polaków, są nimi niewątpliwie: rodzina, wspólnoty lokalne i ojczyzna.

Kolejną kategorię filozofii politycznej, która stała się przedmiotem badań autorów publikacji, jest własność. Z perspektywy tej kategorii, mimo iż własność, nadal zgodnie z doktryną Arystotelesa ma dla Polaków zasadniczo naturalny charakter, jako społeczność okazują się jednak bardziej naśladowcami J. Locke'a, czy J.J. Rousseau.

Respondenci zapytani o opinie na temat własności, pierwszorzędnie połączyli ją z pracą.

Polacy akceptują własność prywatną, ale aprobata ta nie ma charakteru absolutnego i dla znacznej części respondentów wielokrotnie „własność prywatna

\footnotetext{
$8 \quad$ Ibidem, s. 94-95.

9 Ibidem, s. 100-101.

10 Ibidem, s. 102.

11 Ibidem, s. 97.
} 
powinna być podporządkowana dobru wspólnemu"12. Potwierdzenie tego poglądu odnaleźć także można w opiniach Polaków na temat własności publicznej, gdzie większość z respondentów zgodziła się ze stwierdzeniem, że w Polsce „za dużo jest prywatnej własności, a za mało publicznej"13. Tego rodzaju wypowiedzi wskazują, że oczywiście w odniesieniu do własności publicznej, Polacy również w znacznym stopniu podzielają argumentację J. Locke'a. Jednak nadając jej już szerszy wymiar, ich poglądy i przekonania stają się coraz bliższe doktrynie J.J. Rousseau i stanowią klasyczne republikańskie zapatrywanie na dobro wspólne, które, jeżeli zachodzi taka potrzeba, powinno być stawiane ponad dobro prywatne i potrzeby jednostek. Większość respondentów uważa bowiem, że zarówno dobra nierolnicze, takie jak: sieci przesyłowe, kopalnie, poligony wojskowe, czy szpitale, jak i obszary geograficzne: jeziora, rzeki, ich linie brzegowe i lasy powinny zawsze stanowić wyłącznie własność publiczną.

Rozdział czwarty został poświęcony władzy politycznej, która, jak wynika z prezentowanych badań, dla zdecydowanej większości Polaków stanowi integralną część ładu społecznego i jest „naturalnie obecna w każdej społeczności”"14. Poglądy te najbliższe są wizji władzy, jaką prezentowali Arystoteles czy św. Tomasz z Akwinu. Respondenci zgodzili się bowiem z opiniami, które dokładnie odwzorowują myśl Akwinaty twierdząc, że ,jak ludzie żyją razem, ktoś musi im przewodzić", "tak jak w ulu jest królowa, tak musi być przywódca w społeczeństwie"15.

Ostatnią analizowaną kategorią jest państwo. Dla większości respondentów ważne jest, aby opierało się ono na moralnych zasadach i wartościach, które są przez ludzi akceptowane. Troska zaś o ich przestrzeganie i realizowanie moralnych postulatów obywateli, obok dbałości o odpowiednią organizację życia społecznego i ochronę słabszych jednostek stanowią jedno z głównych zadań państwa. Tego rodzaju spostrzeżenia wskazują, że w kwestiach dotyczących państwa wizje Polaków są najbliższe tradycji arystotelesowskiej, jak też szeroko pojmowanej refleksji chrześcijańskiej, a co za tym idzie również współczesnej katolickiej nauce społecznej. Ponadto, jak zauważyli autorzy „Polacy w zdecydowanej większości reprezentują postawę aprobującą kompleksową wspierającą rolę państwa, które na

\footnotetext{
12 Ibidem, s. 114.

13 Ibidem, s. 122.

14 Ibidem, s. 132.

15 Ibidem, s. 143. „Jeśli więc jest naturalne dla człowieka żyć w licznej gromadzie, wobec tego wszyscy potrzebują jakiegoś kierowania całością". Św. Tomasz z Akwinu, O władzy, w: Dzieła wybrane, Kęty 1999, s. 226.
} 
modłę arystotelesowską zaspokaja jak największą część potrzeb swoich obywateli, i to na możliwie najwyższym poziomie"16.

Przeprowadzone badania prowadzą ostatecznie autorów publikacji do przyjęcia stanowiska, że zdaniem Polaków wszystkie z pięciu kategorii filozofii politycznej w swoim założeniu mają naturalny charakter, jednak ich kształt jest każdorazowo „nadany mocą ludzkiej woli”17. Dwie z tych kategorii, człowiek i społeczeństwo, wydają się jednak najważniejsze, stanowiąc dla respondentów wartość samą w sobie. Jest to zauważalne zwłaszcza w odpowiedziach, w których Polacy troszczą się zarówno o dobro jednostki, jak i dobro wspólne. Dobro jednostki obliguje do tego „by społeczeństwo zachowało wspólnotowy charakter, gdyż tylko we wspólnocie człowiek może realizować naturalną potrzebę altruizmu"18. Natomiast dobro wspólne wymaga, aby własność prywatna "gwarantowała społeczeństwu wolnościowy porządek prawny", jednocześnie będąc przy tym ograniczoną przez własność publiczną, gdyż „tylko ona może gwarantować korzystanie z pożytków płynących z własności przez wszystkich bez wyjątku"19. Tego rodzaju założenia odpowiadają zaś najbardziej nurtowi katolickiej nauki społecznej i klasycznemu republikanizmowi.

Polacy są świadomi wagi relacji wspólnotowych i powiązanych z nimi wymagań. Doceniają te więzi, zwłaszcza w kontrze do otoczenia zewnętrznego, które oznacza dla nich wymuszającą konkurencję i konflikty, zatomizowaną zbiorowość. Odpowiedzi respondentów pokazały także, że obywatele zdają sobie sprawę, że zarówno własność prywatna, jak i władza polityczna są tymi czynnikami, które mogą z jednej strony wzmacniać więzi społeczne i osłabiać postawy egoistyczne, z drugiej zaś mieć na nie destrukcyjny wpływ i prowadzić do podziałów społecznych. Naturę Polaków zdaje się zatem najlepiej opisywać spostrzeżenie, że „fakty istnieją obok norm, ale jedne $\mathrm{z}$ drugimi bynajmniej nie pozostają $\mathrm{w}$ zgodzie, lecz tylko łączą się przez dedukcyjne hipotezy"20. To z kolei zdaniem autorów opracowania sytuuje Polaków najbliżej poglądów takich myślicieli jak Arystoteles, J. Locke czy M. Weber.

Niedosyt może pozostawiać jedynie forma i zestawienie pytań, na jakie odpowiadali respondenci. Przyjęta konwencja nie wskazuje jednoznacznie, czy respondenci odpowiadają na zadane pytania, odnosząc je do swoich oczekiwań i poglądów, czy też często wbrew swoim poglądom, na podstawie obserwacji, zakładają,

\footnotetext{
16 Ibidem, s. 185.

17 Ibidem, s. 196.

18 Ibidem.

19 Ibidem, s. 197.

20 Ibidem, s. 200.
} 
że tego rodzaju czynniki stanowią podstawę i motywację zachowań innych. Przykładem może być chociażby zestawienie pytań dotyczących przekonania o wartości rodziny. Z jednej strony pytania „czy zgadza się Pani(i) z poglądem, że rodzina daje nam poczucie bezpieczeństwa, nie ma nic ważniejszego niż rodzina, dzięki rodzinie człowiek ma po co żyć?" w swoim brzmieniu niemal jednoznacznie ukierunkowują respondentów na własne doświadczenia i szukanie odpowiedzi na pytanie, czy dla mnie rodzina jest najważniejsza. Z drugiej zaś pytanie: „czy zgadza się Pani(i) z poglądem, że dla kariery ludzie gotowi są poświęcić rodzinę, ludzie nie dbają o rodzinę?" przekierowuje pytanie na innych, poszukiwanie w pamięci przypadków potwierdzających tego rodzaju zachowania. Co oczywiście w żadnym stopniu nie jest równoważne z pytaniem, „czy dla kariery byłby Pan(i) gotowa poświęcić rodzinę?", które prawdopodobnie wskazałoby odmienne wyniki.

Monografia stanowi interesującą i nowatorską publikację, którą można polecić każdemu, nie tylko prawnikom, politykom, czy socjologom, ale wszystkim tym, którzy chcieliby głębiej poznać i lepiej zrozumieć polskie społeczeństwo.

Jaka jest zatem doktryna Polaków? Czy jako naród jesteśmy konserwatystami, bo aprobujemy ład oparty na społecznej harmonii i uznajemy nienaruszalność „idei społecznej hierarchii autorytetów” w rodzinie, wspólnocie lokalnej, czy w narodzie ${ }^{21}$. Czy też bliżej nam do klasycznego republikanizmu, bo uznajemy dobro wspólne, za dobro wszystkich obywateli, a państwo jest dla nas instytucją, która powinna wyznaczane przez owo dobro cele realizować. A może jednak tak silny sprzeciw wobec ingerencji władzy politycznej w kwestie światopoglądowe, w sferę prywatną i nasze prawa obywatelskie oraz przekonanie, że "podstawą legitymacji państwa jest zgoda społeczeństwa” świadczy o tym, że jesteśmy w rzeczywistości wyznawcami doktryny liberalnej.

Autorzy publikacji określili doktrynę Polaków jako „mozaikę ideową dominujących współcześnie nurtów politycznego myślenia"22. Jaki dokładnie przedstawia ona obraz i gdzie uwidaczniają się na nim wyraźne światłocienie, warto przekonać się, sięgając po tę interesującą i oryginalną lekturę.

\section{Bibliografia}

Makuszyński K., Ponure igraszki, Warszawa-Kraków-Lublin-Łódź-Paryż-PoznańWilno-Zakopane 1927.

Rodzina - jej znaczenie i rozumienie, nr 22, CBOS, Warszawa 2019.

Św. Tomasz z Akwinu, O władzy, w: Dzieła wybrane, Kęty 1999, s. 226.

$\begin{array}{ll}21 & \text { Ibidem, s. } 201 . \\ 22 & \text { Ibidem, s. } 202 .\end{array}$ 